\title{
Influence of Seed Rate and Row Spacing on Growth and Yield of Bread Wheat in Chelia District of West Showa Zone, Ethiopia
}

\author{
Tolcha Tufa $^{1^{*}} \quad$ Haji Kumbi $^{2} \quad$ Tolera Abera $(\mathrm{PhD})^{1}$ \\ 1.Ambo Plant Protection Research Center P.O. Box: 37, Ambo, Ethiopia \\ 2.Holeta Agricultural research Center P.O. Box: 31, Holeta, Ethiopia
}

\begin{abstract}
Wheat (Triticum aestivum L.) is one of the most staple food crops for most of population in Ethiopia. Currently, a number of improved wheat varieties have been released by breeders in Agricultural Research Institutions. The farmers have been produced wheat with traditional agronomic practices which do not improve the wheat yield in country. This experiment was conducted for three cropping season to determine the influence of seed rate and row spacing on growth and yield of bread wheat in Cheliya district on Nitisols of west Shewa Zone. Improved wheat variety (Denda'a) was used and planted with seed rate of 125,150 and $175 \mathrm{~kg} \mathrm{ha}^{-1}$ and in row spacing of 15,20 and $25 \mathrm{~cm}$. The experiment was laid out in randomized complete block design in factorial arrangement with three replications. Main effects seed rate and row spacing were significantly affected mean grain yield and yield components of wheat in the area. Wheat planting with $20 \mathrm{~cm}$ row spacing was significantly produced higher mean grain $\left(5092 \mathrm{~kg} \mathrm{ha}^{-1}\right)$, dry biomass $\left(12142 \mathrm{~kg} \mathrm{ha}^{-1}\right)$, harvest index (42.93), plant height $(99.48 \mathrm{~cm})$ and thousands grain weight $(52.04 \mathrm{~g})$ in three consecutive years. Significantly higher mean tillers number plant ${ }^{-1}$ was recorded from wider row spacing $(25 \mathrm{~cm})$. Seeding rates of wheat was significantly affected mean grain yield, biomass, harvest index, plant height, tiller number per plant and thousand grain of wheat. Significant higher mean grain yields of $4814 \mathrm{~kg} \mathrm{ha}^{-1}$ was obtained from $150 \mathrm{~kg} \mathrm{ha}^{-1}$ seed rate of wheat. Use of $150 \mathrm{~kg} \mathrm{ha}^{-1}$ gave yield advantage of 34.37 and $15.13 \%$ over 125 and $175 \mathrm{~kg} \mathrm{ha}^{-1}$ seed rate of wheat planted with seed rate of $150 \mathrm{~kg} \mathrm{ha}^{-1}$ and $20 \mathrm{~cm}$ row spacing gave higher net benefit of $(33,620$ and 37,200 EB) for wheat producer in the area. Therefore, seed rate of $150 \mathrm{~kg} \mathrm{ha}^{-1}$ and $20 \mathrm{~cm}$ row spacing was recommended for sustainable wheat production in Chelia district and similar agro ecologies.
\end{abstract}

Keywords: wheat, Nitisols seeding rates, row spacing, grain yield

DOI: $10.7176 /$ JNSR/9-5-09

Publication date:March $31^{\text {st }} 2019$

\section{Introduction}

In Ethiopia wheat (Triticum aestivum L.) is one of the most important cereal crops cultivated primarily for human consumption. It has been recognized as strategic food security crop and contributes about $16 \%$ of caloric intake requirement in the country (FAO, 2014). Wheat is cultivated approximately on 1.7 million hectares of land and ranks fourth next to teff, maize and sorghum both in production and area coverage in Ethiopia. It accounts for about $15.17 \%$ of the total cereal production with area coverage of $13.38 \%$ in the country (CSA, 2016). It is widely grown in the mid and highland altitudes within range of 1500 to 3000 meter above sea level in Ethiopia (MOANR, 2016). However, altitude range of 1800 to 2500 masl is favorable for wheat production (Winch, 2007). Wheat crop can grow in different soil types ranging from desert soil to heavy clay soil. However, well drained, fertile clay loam soils having moderate water holding capacity are ideal for better production of wheat crop

Ethiopia is the largest wheat producer in sub-Saharan Africa solely under rain fed condition (Netsanet et al., 2016). Enormous number of improved varieties of wheat were released from research institution by breeders in the country (MOANR, 2016). However, the actual yield of this crop in farmers' field is generally remains below global average yield of wheat crop due to environmental and anthropogenic factors affecting wheat production (Bekele et al., 2000)]. In this regard, inappropriate crop management practices such as low seed rate, improper row spacing, delay in sowing and traditional sowing methods are found to be the key elements contributed to low productivity of wheat crop (Iqbal et al. 2010). For instance, in Ethiopia wheat is planted in broadcast by smallholder farmers for many decades. In spite of high seed rate requirement, broadcasting also results in cluttered plant population which is not suitable for agronomic management and cause inter plant competition for optimum plant nutrients, sunlight, moisture and aeration (Hayatullah et al. 2000; Hamid, 2002; Awake et al., 2017).

However, in developed countries where implementation of farm machineries is available drilling wheat and other crop in row with optimum spacing is common. Row planting result in uniform seed distribution and planting at desired depth and space which usually results in higher germination and uniform stand of the crop (Umed et al., 2009). Higher wheat grain yield with better quality requires appropriate seeding rate and optimum row spacing for different cultivars. Increase in seed rate above optimum level may only enhance production cost without any increase in grain yield (Rafique et al., 2010). As a result, wheat production using row planting is becoming an increasingly accepted management practices in Ethiopia because of yield benefit derived from row planting than broadcasting. In the study area despite to alleviate the aforementioned persistent problems of crop production, 
there has been a growers' interest to increase the productivity through improved agronomic practices. Therefore, the objective this activity was to determine the optimum seed rate and row spacing for bread wheat production in Chelia district of west Shewa Zone.

\section{Materials and Methods}

The experiment was conducted during 2012, 2013 and 2014 cropping seasons for consecutive three years on farmer's field at Cheliya district of west Shewa Zone. Cheliya district is located in Oromia Regional National State at road distance of $184 \mathrm{~km}$ from the capital city of Ethiopia, Addis Ababa. Geographically the district is situated between $8^{\circ} 49^{\prime} 48^{\prime \prime}$ - $9^{\circ} 10^{\prime} 52^{\prime \prime} \mathrm{N}$ and $37^{\circ} 10^{\prime} 6^{\prime \prime}$ - $37^{\circ} 35^{\prime} 18^{\prime \prime} \mathrm{E}$ with an average altitude of 2446 meter above sea level. In specific the experimental site is located in Chelia district at Liban Gamo kebele. Geographically this site is located at $9.0302272^{\circ} \mathrm{N}, 37.4515933^{\circ} \mathrm{E}$ and altitude of $2494 \mathrm{~m}$ meter above sea level.

According to traditional climate classification of Ethiopian the study area is categorized in highland sub humid climate. The area receives mean annual rain fall of $1,026 \mathrm{~mm}$ with unimodal distribution. It has a cool humid climate with the mean minimum, mean maximum, and average air temperatures of $8.51,18.48$, and $13.49^{\circ} \mathrm{C}$, respectively. Cheliya district obtains high rainfall between May to September and low rainfall from December to February (Berhanu et al. 2014).

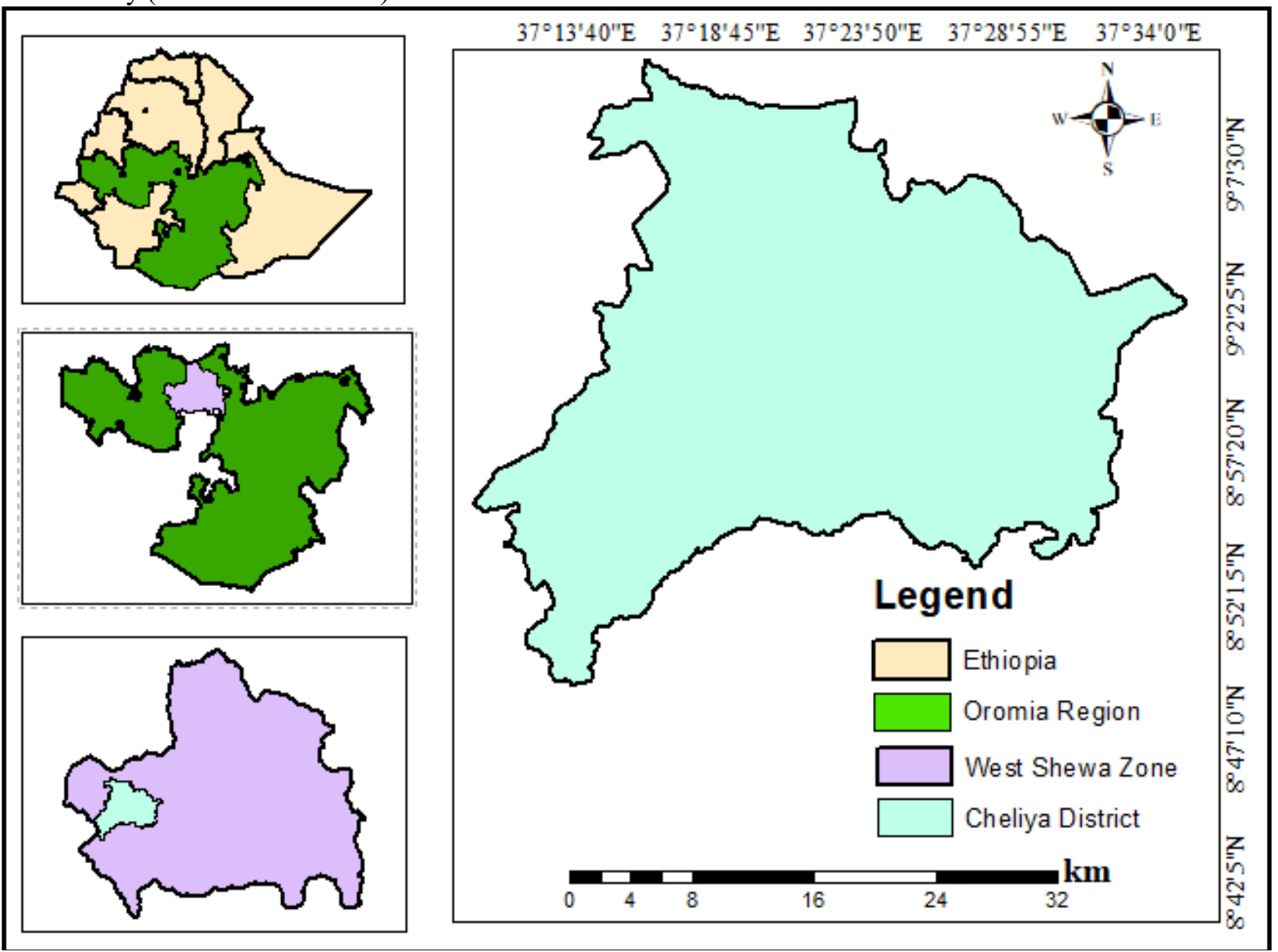

Figure 1. Map of study Area (Chelia District)

The experiment was laid out in randomized complete block design in factorial arrangement with three replications. The plot size was $4.5 \mathrm{~m}$ x $5.10 \mathrm{~m}$. The treatments combinations were three seeding rates $(125,150$ and $\left.175 \mathrm{~kg} \mathrm{ha}^{-1}\right)$ and three row spacing $(15 \mathrm{~cm}, 20 \mathrm{~cm}, 25 \mathrm{~cm})$. The Bread wheat (Denda'a variety) was planted on first week of July. Di-ammonium phosphate with rate of $100 \mathrm{~kg} \mathrm{ha}^{-1}(20 \mathrm{P})$ was subsurface banded in row marked to drill seed during planting. However, Urea fertilizer at rate of $100 \mathrm{~kg} \mathrm{ha}^{-1}$ was subsurface banded at planting and three week post emergence in split and the total of $64 \mathrm{~N}$ (18 N from DAP and 46 from Urea) was applied. Other recommended agronomic practices like ploughing and hand weeding were uniformly for all plots.

At physiological maturity, wheat samples was harvested from $2 \mathrm{~m} \times 2\left(4 \mathrm{~m}^{2}\right)$ quadrant and threshed to measure weight of both grain and dry biomass using digital balance. Therefore, data on growth, yield and yield components were collected from this quadrant before and after harvesting. The plant height $(\mathrm{cm})$ measured from the base of the plant at ground level to the base of spike for 10 randomly selected plants at grain filling stage. Tiller number per plant was taken at maturity stage or near to harvesting time. Dry biomass $\left(\mathrm{kg} \mathrm{ha}^{-1}\right)$, grain yield $\left(\mathrm{kg} \mathrm{ha}^{-1}\right), 1000$ seed weight was recorded at the time of threshing. Harvesting index was calculated from the ratio of grain yield 
to dry biomass times $100(\%)$ indicating the percent of economical yield from total harvested biomass.

All agronomic data were managed and manipulated using Microsoft excel computer software. The arranged crop data was then subjected to analysis of variance (ANOVA) using statistical analysis system (SAS) software (SAS, 2004). List significance Difference (LSD) test at 5\% probability level was also employed to compare mean separation among different treatments.

Partial budget (CIMMYT 1998) was done in order to determine the economic feasibility of using optimum seed rate and row spacing for wheat production in the study area. The mean grain yield was adjusted by subtracting $10 \%$ from both average gain and straw yield to reflect the real farmers' practices. The labour cost and wheat seed during planting were $40 \mathrm{~EB}$ man per day and $9.5 \mathrm{~EB} \mathrm{~kg}^{-1}$, respectively. The mean market price of wheat grain $(8$ $\left.\mathrm{EB} \mathrm{kg}{ }^{-1}\right)$ and straw $\left(0.97 \mathrm{~EB} \mathrm{~kg}^{-1}\right)$ yield were obtained by assessing the market at harvest (2012, 2013 and 2014 cropping season).

\section{Results and Discussion}

\subsection{Over years combined effect of seed rate on yield and yield components of Wheat in Chelia district}

The result of over year combined analysis shows insignificant $(P<0.05)$ effect of seasonal variations on mean plant height, tiller number per plant, dry biomass, grain yield, thousand grain weight and harvest index of wheat (Table 1). This indicates similar trend of climate condition such as rain fall pattern and distribution during three cropping seasons in the study area. Moreover, neither interaction effect of year by Seeding rate nor years by spacing was significant on grain yield and total biomass yield of wheat crop. Similarly, Bhullar and Wali (2004) reported non-significant interaction effect of seed rates and row spacing on yield and yield components of wheat across locations and cropping seasons. Main effect of both seeding rate and row spacing was significantly affected all yield and yield components of wheat across years and locations.

Therefore the main effect of seeding rate and row spacing was discussed in this report. Seeding rates of wheat was significantly $(\mathrm{P}<0.05)$ affected the mean grain yield, dry biomass, harvest index, plant height, tiller number per plant and 1000 seed weight of wheat (Table 2). Likewise, Laghari et al. (2010) reported significant effect of seeding rate on number of tillers, dry matter, leaf area index, 1000 seed weight, grain yield and harvest index of wheat crop. Seed rate had significant effect on mean grain yield of wheat during three years (2012 -2014) cropping seasons in Chelia district of west Shewa zone. Significantly higher mean grain yields $\left(4814 \mathrm{~kg} \mathrm{ha}^{-1}\right)$ of wheat during 2012-2014 were obtained with planting of $150 \mathrm{~kg} \mathrm{ha}^{-1}$ seed rate wheat followed by $4186 \mathrm{~kg} \mathrm{ha}^{-1}$ ) mean grain yield with planting of $175 \mathrm{~kg} \mathrm{ha}^{-1}$ seeding rate but not statistically at par from the mean yield obtained with lowest seeding rate $\left(125 \mathrm{~kg} \mathrm{ha}^{-1}\right)$. Significantly mean grain yield advantage of 34.38 and $14.11 \%$ were obtained from planting of $150 \mathrm{~kg} \mathrm{ha}^{-1}$ seeding rate as compared to use of 175 and $125 \mathrm{~kg} \mathrm{ha}^{-1}$ seeding rate. Similarly Kiliç and Gürsoy (2010) reported significant influence of seeding rate on wheat grain yield and insignificant interaction effect of seed rate and cultivars on grain yield. In contrary, Ghulam et al. (2014) recorded high grain yield and biological yield from seed rate of $125 \mathrm{~kg} \mathrm{ha}^{-1}$ yield than the higher seed rate $\left(150 \mathrm{~kg} \mathrm{ha}^{-1}\right)$ and lower seed rate $(100$ $\mathrm{kg} \mathrm{ha}{ }^{-1}$ ) of wheat cultivars.

Mean dry biomass of wheat was also significantly affected by seed rate of wheat in the study area (Table 12). Significantly higher mean biomass yield $\left(11954 \mathrm{~kg} \mathrm{ha}^{1}\right)$ was obtained from planting of $150 \mathrm{~kg} \mathrm{ha}^{-1}$ seed rate (Table 1). Lower mean dry biomass $\left(9424 \mathrm{~kg} \mathrm{ha}^{-1}\right)$ was recorded from planting of $125 \mathrm{~kg} \mathrm{ha}^{-1}$ seed rate of wheat in the area. The mean combined over year effect of seed rate was not significantly influenced harvest index of wheat (Table 1). Mean Plant height and thousand seed weight of weight was significantly affected by seed rates, with higher mean plant height of $(99.74 \mathrm{~cm})$ and 1000 seed weight $(50.67 \mathrm{~g})$ was obtained from planting of 150 $\mathrm{kg} \mathrm{ha}^{-1}$ seed rate of wheat(Table 1). Mean number of tillers per plant of wheat was also significantly influenced by seed rate. Number of tiller plant of wheat was decreasing with increasing of seed rate. Significantly higher number of tillers plant wheat was recorded from the lower seed rate of $125 \mathrm{~kg} \mathrm{ha}^{-1}$ (Table 1 ).

\subsection{Over years combined effect of row spacing on yield and yield component of wheat in Cheliya district} Over year combined effect of row spacing was significantly affected mean grain yield, dry biomass, plant height, thousand grain weight and effective number of tillers per plant of wheat in Chelia district (Table 1). Higher wheat grain yield of $\left(5091 \mathrm{~kg} \mathrm{ha}^{-1}\right)$ was recorded from $20 \mathrm{~cm}$ row spacing of. Higher mean biomass yield $\left(12142 \mathrm{~kg} \mathrm{ha}^{-1}\right)$ of wheat was obtained from $20 \mathrm{~cm}$ rows pacing and gave advantage of 29 and $17.76 \%$ dry biomass yield of wheat over row spacing $25 \mathrm{~cm}$ and $15 \mathrm{~cm}$ respectively. 
Table 1. Effect of seeding rate and row spacing on durum wheat grain yield and yield components in Cheliya District combined over years (2012-2014)

\begin{tabular}{|c|c|c|c|c|c|c|c|}
\hline \multicolumn{2}{|c|}{ Treatments } & \multirow{2}{*}{$\begin{array}{l}\text { Grain Yield } \\
\left(\mathrm{Kg} \mathrm{ha}^{-1)}\right.\end{array}$} & \multirow{2}{*}{$\begin{array}{c}\begin{array}{c}\text { Dry } \\
\text { biomass } \\
\left(\mathrm{Kg} \mathrm{ha}^{-1)}\right.\end{array} \\
9424.1^{\mathrm{c}}\end{array}$} & \multirow{2}{*}{$\begin{array}{c}\text { Harvest } \\
\text { index (\%) } \\
38.49\end{array}$} & \multirow{2}{*}{$\begin{array}{c}\text { Plant } \\
\text { height } \\
(\mathrm{cm})\end{array}$} & \multirow{2}{*}{$\begin{array}{c}\begin{array}{c}\text { Tiller } \\
\text { number } \\
\text { per plant }\end{array} \\
7.3^{\mathrm{a}}\end{array}$} & \multirow{2}{*}{$\begin{array}{c}1000 \text { seed } \\
\text { weight }(\mathrm{g})\end{array}$} \\
\hline Seed rating & 125 & & & & & & \\
\hline \multirow[t]{3}{*}{$\mathrm{Kg} \mathrm{ha}^{-1}$} & 150 & $4813.7^{\mathrm{a}}$ & $11953.6^{\mathrm{a}}$ & 41.12 & $99.74^{\mathrm{a}}$ & $6.5^{\mathrm{b}}$ & $50.667^{\mathrm{a}}$ \\
\hline & 175 & $4181.11^{\mathrm{b}}$ & $10478.7^{b}$ & 40.48 & $90.78^{\mathrm{b}}$ & $5.5^{\mathrm{c}}$ & $46.26^{\mathrm{b}}$ \\
\hline & LSD & 6.99 & 12.55 & 14 & 3.75 & 0.36 & 2.13 \\
\hline \multirow{3}{*}{$\begin{array}{l}\text { Row spacing } \\
(\mathrm{cm})\end{array}$} & 15 & $3586.67^{\mathrm{c}}$ & $9403.7^{\mathrm{c}}$ & $38.92^{\mathrm{b}}$ & $95.07^{\mathrm{b}}$ & $5.9^{\mathrm{b}}$ & $43.04^{\mathrm{c}}$ \\
\hline & 20 & $5091.48^{\mathrm{a}}$ & $12141.9^{\mathrm{a}}$ & $42.93^{\mathrm{a}}$ & $99.48^{\mathrm{a}}$ & $6.6^{\mathrm{a}}$ & $52.04^{\mathrm{a}}$ \\
\hline & 25 & $3899.15^{\mathrm{b}}$ & $10310.8^{b}$ & $38.24^{\mathrm{b}}$ & $97.04 b^{a}$ & $6.8^{\mathrm{a}}$ & $48.19^{\mathrm{b}}$ \\
\hline \multicolumn{2}{|l|}{$\mathrm{LSD} 5 \%$} & 159.72 & 726.75 & 3.06 & 3.75 & 0.36 & 2.13 \\
\hline \multicolumn{2}{|l|}{ CV\% } & 6.99 & 12.55 & 14 & 7.1 & 10.5 & 8.2 \\
\hline \multicolumn{2}{|l|}{$\mathrm{SR} * \mathrm{RS}$} & NS & Ns & Ns & NS & Ns & NS \\
\hline \multicolumn{2}{|l|}{ Year*SR } & NS & NS & NS & $*$ & Ns & $*$ \\
\hline \multicolumn{2}{|l|}{ Year*RS } & NS & $*$ & $*$ & $*$ & Ns & $* *$ \\
\hline
\end{tabular}

$\mathrm{SR}=$ seeding rate, $\mathrm{RS}=\mathrm{Row}$ spacing, ${ }^{*}=$ significant $\alpha \leq 0.05$ and $* *=$ highly significant $\alpha \leq 0.01$, $\mathrm{S}=$ non-significant difference at $5 \%$ probability level, Numbers followed by the same latter in the same column are not significant difference at $5 \%$ probability level.

Significantly higher mean harvest index (42.93) and thousand seed weigh (52 g) of wheat were obtained from wheat planted with $20 \mathrm{~cm}$ row spacing. The mean combined over year effect of 20 and $25 \mathrm{~cm}$ row spacing of wheat was showed significant effects of mean plant height of wheat as compared to the narrower row spacing $(15 \mathrm{~cm})$. Higher mean plant height $99.48 \mathrm{~cm}$ followed by $97.04 \mathrm{~cm}$ of wheat was recorded from $20 \mathrm{~cm}$ and $25 \mathrm{~cm}$ row spacing, respectively. The mean number of tiller plant of wheat was indicated significantly increasing with increasing of row spacing of wheat. Wider row spacing $(20$ and $25 \mathrm{~cm})$ were produced significantly higher thousand seed weight than narrower row spacing (Table 1).

\subsection{Effect of seeding rate on wheat yield and yield component in 2012, 2013 and 2014 cropping seasons}

Interaction effects of seeding rate and row spacing was nonsignificant on yield and yield components of wheat (Table 2). Main effect of both seed rate and row spacing revealed significant $(\mathrm{P}<0.05)$ effect on yield and yield components of wheat except thousand grain weight, dry biomass and harvest index in 2012 and harvest index wheat in 2014 cropping season (Table 2). Mean grain yield of wheat was significantly influenced by seeding rate in 2012, 2013 and 2014 cropping seasons. Higher mean grain yield of 5361,5113 and $4800 \mathrm{~kg} \mathrm{ha}^{-1}$ were recorded from used $150 \mathrm{~kg} \mathrm{ha}^{-1}$ seed rate during three consecutive cropping seasons. In 2013 cropping season significance variation among yield was obtained from 125 and $150 \mathrm{~kg} \mathrm{ha}^{-1}$ at par, but both were significantly yielded more than $175 \mathrm{~kg} \mathrm{ha}^{-1}$ seeding rate.

Main effect of seed rate was significant $(\mathrm{P}<0.05)$ effects on mean biomass yield of wheat in 2013 and 2014 cropping seasons (Table 2). The use of $150 \mathrm{~kg} \mathrm{ha}^{-1}$ seed rate of wheat was gave yield advantage of 6.6 and $11.6 \%$ over $175 \mathrm{~kg} \mathrm{ha}^{-1}$ and $125 \mathrm{~kg} \mathrm{ha}^{-1}$ seed rate, respectively. Mean harvest index of wheat was significantly affected by different seed rate of wheat in 2012 and 2014 cropping seasons. Significantly higher harvest index (48.86) of wheat was recorded from $150 \mathrm{~kg} \mathrm{ha}^{-1}$ seeding rate during 2012 cropping season. In 2012 cropping season the mean grain yield harvested from $150 \mathrm{~kg} \mathrm{ha}^{-1}$ seed rate was significantly varied seed rate $\left(175 \mathrm{~kg} \mathrm{ha}^{-1}\right)$ and lowest seed rate $\left(125 \mathrm{~kg} \mathrm{ha}^{-1}\right)$. Harvest index of wheat did not respond to increased seeding rate in 2014 as compared 2012 and 2013 cropping seasons (Table 2).

Plant height is important growth parameter that indicates the condition in which the crop was grown. The variety of all crops have optimum plant height at which better yield was obtained at the same time. Therefore, crop yield reduction was induced when the crop favored less and over the optimum condition. Significantly lower mean plant height was recorded from seed rate $\left(175 \mathrm{~kg} \mathrm{ha}^{-1}\right)$ of wheat in 2012, 2013 and 2014 cropping seasons. Similar plant height of wheat was obtained from 125 and $150 \mathrm{~kg} \mathrm{ha}^{-1}$ seed rate of wheat in three years.

Mean thousand seed weight is important yield component that has always a close relation with any crop grain yield, unless sampling was biased the result. Thousand seed weight of wheat was significantly influenced by wheat seed rates in 2013 and 2014 cropping seasons (Table 3) but non-significant in 2012 cropping season

3.4 Effect of row spacing on yield and yield component of wheat in 2012, 2013 and 2014 cropping seasons The mean analysis result of yield and yield components of wheat due to row spacing are presented in Table 2 and 3 . The effect of row spacing on grain yield of wheat was indicated similar trend and significant affected in three cropping seasons. Significantly higher mean grain yield 4894, 4969 and $4578 \mathrm{~kg} \mathrm{ha}^{-1}$ was obtained in 2012,2013 
and 2014 respectively at $20 \mathrm{~cm}$ row spacing. Lower grain yield of wheat were consistently obtained from use of $(15 \mathrm{~cm})$ row spacing during three cropping seasons. Planting of Denda'a wheat variety in $20 \mathrm{~cm}$ row spacing can provide better mean grain yield as compared to $(15 \mathrm{~cm})$ and $(25 \mathrm{~cm})$ row spacing. Mean dry biomass of wheat was significantly influenced by different row spacing except in 2012 cropping season. During 2013 and 2014 significantly higher mean biomass yield was recorded from $20 \mathrm{~cm}$ row spacing and followed by $25 \mathrm{~cm}$ row spacing. Higher mean biomass (13366 kg ha-1) was recorded from $20 \mathrm{~cm}$ row spacing in 2013, while lower $\left(7911 \mathrm{~kg} \mathrm{ha}^{-1}\right)$ biomass yield was obtained from $(15 \mathrm{~cm})$ row spacing of wheat in 2014 .

Higher mean harvest index of wheat was observed from $20 \mathrm{~cm}$ row spacing in 2012 and 2013. Better harvest index of 47, 39 and 40\% was recorded in 2012, 2013 and 2014 respectively.

Table 2. Effect of seeding rate and row spacing on grain yield, total biomass yield and harvest index of durum wheat in Cheliya districts

\begin{tabular}{|c|c|c|c|c|c|c|c|c|c|c|}
\hline \multirow[b]{2}{*}{ Treatments } & & \multicolumn{3}{|c|}{2012} & \multicolumn{3}{|c|}{2013} & \multicolumn{3}{|c|}{2014} \\
\hline & & $\begin{array}{c}\text { Grain } \\
\text { Yield } \\
\left(\mathrm{Kg} \mathrm{ha}^{-1}\right)\end{array}$ & $\begin{array}{c}\text { Dry } \\
\text { biomass } \\
\left(\begin{array}{c}\mathrm{Kg} \mathrm{ha}^{-} \\
1\end{array}\right)\end{array}$ & $\begin{array}{c}\text { Harvest } \\
\text { index } \\
(\%)\end{array}$ & $\begin{array}{c}\text { Grain } \\
\text { Yield } \\
\left(\mathrm{Kg} \mathrm{ha}^{-}\right. \\
\left.{ }^{1}\right)\end{array}$ & $\begin{array}{c}\text { Dry } \\
\text { biomass } \\
\left(\begin{array}{c}\mathrm{Kg} \mathrm{ha}^{-} \\
1\end{array}\right)\end{array}$ & $\begin{array}{c}\text { Harvest } \\
\text { index } \\
(\%)\end{array}$ & $\begin{array}{c}\text { Grain } \\
\text { Yield } \\
\left(\begin{array}{c}\mathrm{Kg}^{1} \mathrm{ha}^{-} \\
1\end{array}\right)\end{array}$ & $\begin{array}{c}\text { Dry } \\
\text { biomass } \\
\left(\begin{array}{c}\mathrm{Kg} \text { ha }^{-} \\
1\end{array}\right)\end{array}$ & $\begin{array}{c}\text { Harvest } \\
\text { index } \\
(\%)\end{array}$ \\
\hline Seed & 125 & $3783.3^{\mathrm{b}}$ & 9522.2 & $41.42^{b}$ & $3826.7^{\mathrm{c}}$ & $10877.9^{b}$ & $35.15^{\mathrm{b}}$ & $3166.7^{c}$ & $7833.3^{\mathrm{c}}$ & 40.19 \\
\hline rate $\mathrm{Kg}$ & 150 & $5361.1^{\mathrm{a}}$ & 10622.2 & $49.85^{\mathrm{a}}$ & $5113.3^{\mathrm{a}}$ & $13847.9^{\mathrm{a}}$ & $36.84^{\mathrm{a}}$ & $4800^{\mathrm{a}}$ & $11966.7^{\mathrm{a}}$ & 40.09 \\
\hline ha-1 & 175 & $3927.8^{b}$ & 9966.7 & $39.77^{\mathrm{b}}$ & $4179.1^{\mathrm{b}}$ & $11687.9^{b}$ & $35.71^{\text {ba }}$ & $3588.9^{\mathrm{b}}$ & $9300^{\mathrm{b}}$ & 39.23 \\
\hline LSD & & 241.1 & $\mathrm{NS}$ & 10.06 & 300.26 & 883.02 & 1.15 & 368.4 & 1148.6 & $\mathrm{NS}$ \\
\hline Row & 15 & $3761.1 \mathrm{c}$ & 9533.3 & 40.157 & $3812.4^{\mathrm{c}}$ & $10833.3^{c}$ & 35.16 & $3188.9^{c}$ & $7911.1^{\mathrm{c}}$ & 40.2 \\
\hline spacing & 20 & $4894.4 \mathrm{a}$ & 10777.8 & 47.02 & $4968.9^{\mathrm{a}}$ & $13366.4^{\mathrm{a}}$ & 37.09 & $4577.8^{\mathrm{a}}$ & $11744.4^{\mathrm{a}}$ & 39.2 \\
\hline$(\mathrm{cm})$ & 25 & $4416.7 \mathrm{~b}$ & 9800 & 45.858 & $4337.8^{b}$ & $12213.9^{b}$ & 35.45 & $3788.9^{\mathrm{c}}$ & $9444.4^{\mathrm{b}}$ & 40.1 \\
\hline $\operatorname{LSD}(5 \%)$ & & 241.1 & $\mathrm{NS}$ & NS & 300.26 & 883.02 & 1.15 & 368.44 & 1148.6 & Ns \\
\hline CV\% & & 12.54 & 19.31 & 22.69 & 6.87 & 7.3 & 3.2 & 9.57 & 11.85 & 13.88 \\
\hline
\end{tabular}

$\mathrm{S}=$ non-significant difference at $5 \%$ probability level, Numbers followed by the same latter in the same column are not significant difference at $5 \%$ probability level.

Table 3.Effect of seeding rate and row spacing on plant height, tiller number and thousand seed weight of wheat in Cheliya Districts

\begin{tabular}{|c|c|c|c|c|c|c|c|c|c|c|}
\hline \multirow[t]{2}{*}{ Treatment } & & \multicolumn{3}{|c|}{2012} & \multicolumn{3}{|c|}{2013} & \multicolumn{3}{|c|}{2014} \\
\hline & & $\begin{array}{l}\text { Plant } \\
\text { height } \\
(\mathrm{cm})\end{array}$ & $\begin{array}{c}\text { Tiller } \\
\text { number } \\
\text { per } \\
\text { plant }\end{array}$ & $\begin{array}{c}1000 \\
\text { grain } \\
\text { weight } \\
(\mathrm{g})\end{array}$ & $\begin{array}{l}\text { Plant } \\
\text { height } \\
(\mathrm{cm})\end{array}$ & $\begin{array}{c}\text { Tiller } \\
\text { number } \\
\text { per } \\
\text { plant }\end{array}$ & $\begin{array}{c}1000 \\
\text { grain } \\
\text { weight } \\
(\mathrm{g})\end{array}$ & $\begin{array}{l}\text { Plant } \\
\text { height } \\
(\mathrm{cm})\end{array}$ & $\begin{array}{c}\text { Tiller } \\
\text { number } \\
\text { per } \\
\text { plant }\end{array}$ & $\begin{array}{l}1000 \\
\text { grain } \\
\text { weight } \\
\text { (g) }\end{array}$ \\
\hline Seeding & 125 & $100.2 \mathrm{a}$ & $6.71 \mathrm{a}$ & 47.48 & $100.96 a$ & $7.52 \mathrm{a}$ & $49.61 \mathrm{a}$ & $96.76 \mathrm{a}$ & $8 \mathrm{a}$ & $47.89 \mathrm{~b}$ \\
\hline rate $\mathrm{kg}$ & 150 & $98.54 \mathrm{ba}$ & $5.73 b$ & 49.36 & $99.61 \mathrm{a}$ & $7.32 \mathrm{a}$ & $47 \mathrm{ba}$ & $95.70 \mathrm{a}$ & $7 b$ & $55.78 \mathrm{a}$ \\
\hline $\mathrm{ha}^{-1}$ & 175 & $88.87 \mathrm{~b}$ & $4.69 c$ & 46.28 & $90.84 b$ & $6.79 b$ & $44.7 b$ & $87.8 \mathrm{~b}$ & $5 c$ & $41.74 c$ \\
\hline $\operatorname{LSD}(5 \%)$ & & 9.95 & 0.55 & NS & 4.91 & 0.33 & 4.5 & 1.89 & 1.1 & 3.7 \\
\hline Row & 15 & $87.29 b$ & $5.24 b$ & $44.61 \mathrm{~b}$ & $94.56 b$ & $6.88 b$ & $42.72 b$ & $85.22 b$ & $6 b$ & $41.5 \mathrm{c}$ \\
\hline spacing & 20 & $100.07 \mathrm{a}$ & $5.88 \mathrm{a}$ & $49.02 \mathrm{a}$ & $96.52 \mathrm{ba}$ & $7.27 \mathrm{a}$ & $49.10 \mathrm{a}$ & $96.67 \mathrm{a}$ & $7 a$ & $52 \mathrm{a}$ \\
\hline$(\mathrm{cm})$ & 25 & $100.26 a$ & $6 a$ & $49.49 \mathrm{a}$ & $100.33 \mathrm{a}$ & $7.49 \mathrm{a}$ & $49.34 \mathrm{a}$ & $98.41 \mathrm{a}$ & $7 a$ & $45.91 \mathrm{~b}$ \\
\hline $\operatorname{LSD}(5 \%)$ & & 9.95 & 0.55 & 9.95 & 3.69 & 4.91 & 0.33 & 4.5 & 1.89 & 1.1 \\
\hline CV $(\%)$ & & 10.38 & 9.6 & 10.38 & 7.74 & 5 & 4.6 & 9.71 & 7.02 & 16.55 \\
\hline
\end{tabular}

$\mathrm{NS}=$ non-significant difference at $5 \%$ probability level, Numbers followed by the same latter in the same column are not significant difference at $5 \%$ probability level.

\subsection{Effect of seeding rate and row spacing on economic feasibility of wheat production}

The partial budget analysis due to seed rate and row spacing for wheat are indicated in Table 4. The value to cost ratio of wheat due to seed rate and row spacing was ranged from $3.39-5.43$ and 3.77 to 5.57 EB per unit of investment respectively (Table 4). Higher value to cost ratio of 5.43 was obtained with $150 \mathrm{~kg} \mathrm{ha}^{-1}$ seed rate wheat was used per unit of investment. Better value to cost ratio of 5.57 of wheat was obtained from $20 \mathrm{~cm}$ row spacing of wheat. Therefore, farmer could earn a profit of 5.57 EB per unit of investment when a wheat was cultivated with $20 \mathrm{~cm}$ row spacing in Chelia district. The he highest net benefit of 33,620 EB with marginal rate of return $115.27 \%$ followed by $25090 \mathrm{~EB} \mathrm{ha}^{-1}$ of wheat were obtained from using of 150 and $175 \mathrm{~kg} \mathrm{ha}^{-1} \mathrm{seed}$ rate of wheat, respectively. Higher net benefit of 37,200 EB with marginal rate of return $2886 \%$ of wheat was obtained from $20 \mathrm{~cm}$ row spacing wheat production in the area. Therefore, planting of wheat with 150 seed rate and $20 \mathrm{~cm}$ row spacing was economically feasible agronomic practices for wheat production in Chelia district of west Shewa Zone. 
Table 3. Effect of seeding rate and row spacing on economic feasibility of wheat production in Cheliya district

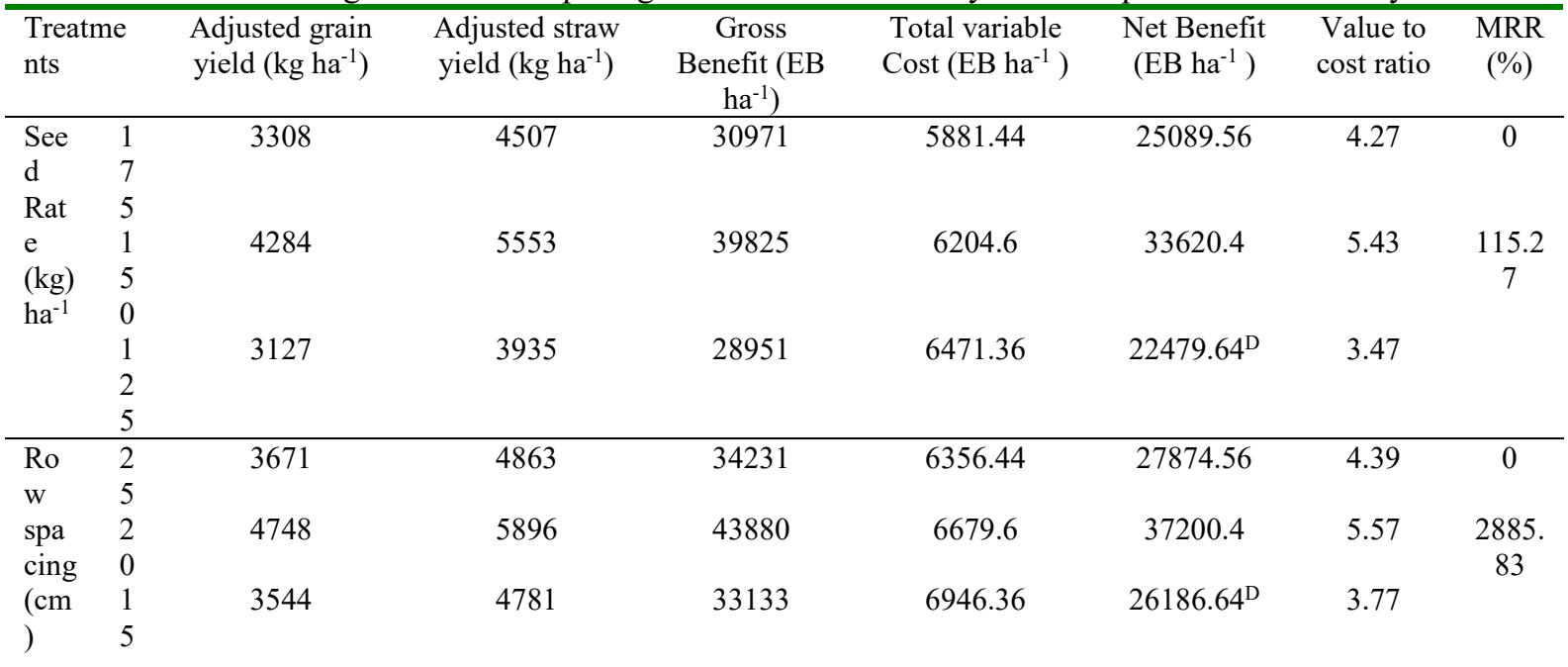

Wheat seed cost $=9.5 \mathrm{~EB} \mathrm{~kg}^{-1}$, wheat grain price $=8 \mathrm{~EB} \mathrm{~kg}^{-1}$ and wheat straw price $=0.97 \mathrm{~EB} \mathrm{~kg}^{-1}$, Labor cost $=$ 40 ETB per day. MRR: Marginal rate of return and ETB: Ethiopian birr, TVC: Total variable Cost and, $\mathrm{D}=$ Dominated minimum rate of return $=100 \%$

\section{Conclusion}

Seed rate and row spacing was significantly influenced grain yield and yield components of wheat in 2012 2014cropping seasons in Cheliya district. Significantly higher grain yield, dry biomass, harvest index, 1000 grain weight and plant height of wheat were recorded from $150 \mathrm{~kg} \mathrm{ha}^{-1}$ seed rate of wheat in three years. Lower seed rate $125 \mathrm{~kg} \mathrm{ha}^{-1}$ was produced the highest number of tillers per plant in all cropping seasons. Row spacing was also primarily influenced yield and yield components of wheat crop in the study area. Higher mean grain yield and dry biomass was recorded from $20 \mathrm{~cm}$ in three cropping seasons. The use of $150 \mathrm{~kg} \mathrm{ha}^{-1}$ seeding rate and $20 \mathrm{~cm}$ row spacing of wheat were gave higher net benefit of (33,620 and 37,200 EB) and marginal rate of return (115.27 and $2885.83 \%$ ) of wheat. In conclusion, $150 \mathrm{~kg} \mathrm{ha}^{-1}$ and $20 \mathrm{~cm}$ seed rate row spacing of wheat produced higher grain yield and dry biomass of wheat in Cheliya district of west Showa Zone. Therefore, $150 \mathrm{~kg} \mathrm{ha}^{-1} \mathrm{and} 20 \mathrm{~cm}$ row spacing was recommended for Danda'a wheat variety production Cheliya district and similar agro-ecologies.

\section{Acknowledgments}

The authors gratefully acknowledge the generous financial support from Ethiopian Institute of Agricultural Research for ultimate success of this experiment. They are also thankful to Ambo Agricultural Research Center and staff members for facilitating important logistics for field and laboratory work. The authors also express their special thanks to all field and technical assistants of natural Resource Management Research Process for their unreserved work in preparation of input, field management and data collection in the field. Finally, the authors gratefully appreciate the Farmers of Liban Gamo Kebele of Chelia District to allow their farm for the experiment.

\section{References}

Al-Fakhry, A. K. and Y. A. Ali. 1989. Effect of plant densities and fertilization on yield of two wheat cultivars (Triticum aestivum L.) under rainfed conditions in Northern Iraq. Mesopotamia Journal of Agriculture. 21(1):221-236

Awoke Tadesse, Tekle Yoseph, and Misgana Mitiku. 2017. Effect of sowing methods and seed rate on yield of bread wheat (triticum aestivum 1.) At south ari district, south omo zone, SNNP Ethiopia. International Journal of Research, 5(6), 175-180.

Baltenesperger, K. M. Eskridge, M. J. Shipman and D. R. Shelton.2002. Seeding rate and genotype effect on agronomic performance and end-use quality of winter wheat. Crop Science 42(3):827-832

Bhullar, M. S. and U. S. Wali. 2004. Effect of seed rate and row spacing on the efficiency of clodinafop for combating isoproturan resistant Phalaris minor in wheat. Plant Protection-Quarterly. 19(4):143-146

Birhanu Bayeh.2010.Assessment of bread wheat production, marketing and selection of N-efficient bread wheat (tritium aestivum 1.) varieties for higher grain yield and quality in north western Ethiopia.Msc.Thesis may. Bahir Dar University,Ethiopia

CIMMYT. 1988. From agronomic data to farmer recommendations: An Economics Training Manual. Completely revised edition. Mexico. D.F. 
CSA (Central Statistical Agency). 2016. Agricultural Sample Survey 2015/16 (2008 E.C) volume I: Technical Report on Area and Production for Major Crops. Statistical Bulletin No. 584.Addis Ababa, Ethiopia

FAO. 2014. Food Balance Sheets." Rome, Italy. Accessed on November 2018 and from: http://faostat.fao.org/site/368/DesktopDefault.aspx?PageID=368\#ancor

Hamid M.A., M.Z. Islam, M. Biswas, A.A. Begum, M. Saifullah and M. Asaduzzaman, 2002. Effect of Method of Sowing and Seed Rate on the Growth and Yield of Soybean. Pakistan Journal of Biological Sciences, 5: $1010-1013$

Hasan K., Songül G.2010.Effect of seeding rate on yield and yield components of durum wheat cultivars in cottonwheat cropping system. Scientific Research and Essays Vol. 5(15): 2078-2084

Hayatullah Khan, Muhammad Ayaz Khan, Iqtidar Hussain, Muhamad Zaman Khan and Masood Khan Khattak. 2000. Effect of Sowing Methods and Seed Rates on Grain Yield and Yield Components of Wheat Variety Pak-81. Pakistan Journal of Biological Sciences, 3: 1177-1179

Iqbal N., Akbar N., Ali M., Sattar M. and Ali L. 2010. Effect of seed rate and row spacing on yield and yield components of wheat (Triticum aestivum L.), J. Agric. Res., , 48(2) pp 151-155

Kiliç H. and Gürsoy S.2010. Effect of seeding rate on yield and yield components of durum wheat cultivars in cotton-wheat cropping system. Academic Journals, Vol. 5(15), pp. 2078-2084

Laghari, G.M., F.C. Oad, S. Tunio, Q. Chachar, A.W. Ghandahi, M.H. Siddiqui, S.W. Hassan and A. Ali. 2010. Growth and yield attributes of wheat at different seed rates. Sarhad J. Agric. 27(2): 177-183

MOANR (Ministry of agriculture and Natural resource): Plant variety release, protection and seed quality control directorate. 2016. Crop Variety register. Issue No.19. Addis Ababa, Ethiopia

Iqbal N., N. Akbar, M. Ali, M. Sattar and L. Ali.Effect of seed rate and row spacing on yield and yield components of wheat (triticum aestivum 1.). J. Agric. Res., 2010, 48(2):151-156

Negassa, A., B. Shiferaw, Jawoo Koo, K. Sonder, M. Smale, H.J. Braun, S. Gbegbelegbe, Zhe Guo, D. Hodson, S. Wood, T. Payne, and B. Abeyo. 2013. The Potential for Wheat Production in Africa: Analysis of Biophysical Suitability and Economic Profitability. Mexico, D.F.: CIMMYT

Netsanet H., Ali. S. H. and Laing M. 2016. Appraisal of farmers' wheat production constraints and breeding priorities in rust prone agro-ecologies of Ethiopia. African Journal of Agricultural Research. 12(12), pp. 944952

Rafique SM, Rashid M, Akram MM, Ahmad J, Hussain R, Razzaq A (2010). Optimum seed rate of wheat in available soil moisture under rainfed conditions. J. Agric.Res. 47(2)

Ram, K., T. Sing, H. Singh and A. S. Faroda. 1988. Effect of seed rate and spacing on grain yield of late sown wheat variety WH-291. Haryana Agri. Uni. J. Res. 18(1):26-28

SAS (Statistical Analysis Software). 2002. SAS/STAT Software Syntax, Version 9.0. SASInstitute, Cary, NC, USA.

Tesfaye S., Bedada B. and Mesay Y. 2016. Impact of improved wheat technology adoption on productivity and income in Ethiopia. African Crop Science Journal by African Crop Science Society .Vol. 24, Issue Supplement s1, pp. $127-135$

Umed Ali Soomro, Mujeeb Ur Rahman, Ejaz Ali Odhano, Shereen Gul and Abdul Qadir Tareen. 2009. Effects of Sowing Method and Seed Rate on Growth and Yield of Wheat (Triticum aestivum). World Journal of Agricultural Sciences 5 (2): 159-162

Winch T. 2007. Growing Food: A Guide to Food Production. Springer-Verlag. New York Inc., United States. http://www.agriinfo.in. My agriculture Information Bank.

Ghulam Shah Nizamani, Shamsuddin Tunio, Umed Ali Buriro, Muhammad Ibrahim Keerio. Influence of Different Seed Rates on Yield Contributing Traits in Wheat Varieties. Journal of Plant Sciences. Vol. 2, No. 5, 2014, pp. 232-236. doi: 10.11648/j.jps.20140205.2

Bekele Hundie, Kotu. H, Verkuijl, W. Mwangi and D. Tanner. 2000. Adoption of Improved wheat Technologies in Adaba and Dodola Woredas of the Bale Highlands, Ethiopia. Mexico, D .F.: International Maize and Wheat Improvement Center (CIMMYT) and Ethiopian Agricultural Research Organization (EARO).

Birhanu Kebede, Teshome Soromessa and Ensermu Kelbessa. 2014. Structure and Regeneration Status of Gedo Dry Evergreen Montane Forest, West Shewa Zone of Oromia National Regional State, Central Ethiopia. Science, Technology and Arts Research Journal, 3(2): 119-131 